\title{
Protein Fortification of Corn Tortillas: Effects on Physicochemical Characteristics, Nutritional Value and Acceptance
}

\author{
Abril Lecuona-Villanueva, David A. Betancur-Ancona, Luis A. Chel-Guerrero, \\ Arturo F. Castellanos-Ruelas*
}

Faculty of Chemical Engineering, Autonomous University of Yucatán, Campus of the Faculties of Engineering and Math Sciences, Mérida, México.

Email: *cruelas@uady.mx

Received October $9^{\text {th }}, 2012$; revised November $9^{\text {th }}, 2012$; accepted November $17^{\text {th }}, 2012$

\begin{abstract}
The aim of this study was to evaluate the texture of corn dough as well as the nutritional quality and acceptance of corn cakes (tortillas) made either with a readymade commercial corn flour (CCF) or with a traditional way (nixtamal) both fortified with lys $+\operatorname{tryp}(\mathrm{L}+\mathrm{T})$ or with a protein concentrate from Phaseolus lunatus added with $\mathrm{L}+\mathrm{T}(\mathrm{PC}+\mathrm{L}+\mathrm{T})$. All treatments were analyzed to investigate the physical properties of the dough and tortillas as well as their physicochemical and nutritional quality. Results showed that cohesion was affected $(p<0.05)$ in the fortified tortillas made with CCF decreasing from 34.3 to 28.4 and $27.4 \mathrm{~N}$ for Control, $\mathrm{L}+\mathrm{T}$ and $\mathrm{PC}+\mathrm{L}+\mathrm{T}$, respectively; tortillas made with nixtamal showed no difference. Adhesion was not affected by treatments. Weight loss increased only in the fortified tortillas made with CCF $(p<0.05)$. Rolling capacity was not affected by fortification. The tension of tortillas increased with the fortification being the highest value $0.96 \mathrm{~N}$. Color was not affected in tortillas made with CCF $(p<0.05)$; changes observed in those made with nixtamal remained in an acceptable range. In vitro digestibility was improved by the fortification obtaining the highest values in tortillas made with $\mathrm{CCF}$ and fortified with $\mathrm{PC}+\mathrm{L}+\mathrm{T}$. Acceptance was greater for tortillas fortified with $\mathrm{L}+\mathrm{T}$ alone. Protein fortification of tortillas made with either CCF or nixtamal is feasible using either $\mathrm{L}+\mathrm{T}$ together or in combination with a PC from Phaseolus lunatus improving their nutritional value without negative effects on their physicochemical characteristics or acceptance.
\end{abstract}

Keywords: Tortilla; Amino Acids; Child Malnutrition; Fortification

\section{Introduction}

México, with a population of approximately 112 million inhabitants [1] is the country with the largest consumption of corn per capita in the world. Tortillas (baked corn cakes) and related products made of corn are largely consumed by the population, especially in the lower socioeconomic levels of population [2]. Average per capita consumption is estimated at $240 \mathrm{~g} /$ day and in rural areas this figure rises to $400 \mathrm{~g} /$ day [3]. This consumption meets the daily requirements of about $45 \%$ of total calories, $39 \%$ of protein and $49 \%$ of calcium; in rural areas as much as $70 \%$ of total calories and $50 \%$ of protein are provided by corn [4].

Unfortunately, corn is not a balanced food because it lacks the essential amino acids lysine and tryptophan [5, $6]$.

FAO in its latest estimates [7] indicated that in 2010

"Corresponding author. the world had 925 million undernourished people, of which $98 \%$ were in developing countries. In México, protein-energy malnutrition affects approximately onefifth of the rural population, about five million people, while in urban areas affects seven percent of the population, as noted by the National Health and Nutrition Survey [8].

Fortification is the nutritional improvement of food by the addition of nutrients such as vitamins, minerals and amino acids (or other protein supplements). Fortification strategies seeks to benefit in the shortest time, most of the population suffering from malnutrition, improving the quality of the food that make up the bulk of the diet [9]. Because of its high consumption, tortillas can be used as a vehicle to reduce protein malnutrition. Early research on tortilla in Mexico was made in the 50's by the National Institute of Nutrition. Fortification was carried out with chickpeas, beans and milk; soybean meal and sesame protein; amaranth flour; Phaseolus lunatus 
protein concentrate [10-13]. In Nigeria soybeans were also used for the same purpose [14]. Although important progress has been made, some strategies have altered taste, color or in cases the tortilla hardens faster [9].

Fortification was achieved with other cons products. Fried snack with various mixtures of beans and corn, were tested showing that the best mix from the standpoint of protein content and sensory characteristics was a ratio of 50:50 (w/w) [15]. Other snacks made with mixes of fried kernels of three cultivars of beans and yellow dent corn in the same proportion, improved the biological value of proteins [16]. The traditional tamales (corn patties) prepared with a mixture of corn and soybeans precooked by extrusion, improved the amino acid balance [17].

\section{Materials and Methods}

Two types of corn dough were prepared, using:

- Commercial corn flour (CCF). Cornmeal trade mark Maseca ${ }^{\circledR}$ readymade to elaborate tortillas.

- Kernels of native maize (X'nuknal yellow) submitted to the traditional preparation prior to the elaboration of tortillas (nixtamal).

Two types of fortification were used:

- Amino acids lysine and tryptophan $(\mathrm{L}+\mathrm{T})$, Teklan Harlan brand.

- Protein concentrate (PC) from Phaseolus lunatus beans added with $\mathrm{L}+\mathrm{T}$.

The fortification of tortillas was designed to meet $100 \%$ of the requirements established by the $\mathrm{FAO} / \mathrm{WHO}$ (1991) for lysine and tryptophan [6]. Tortillas without fortification were used as a Control group.

Concentrate protein of Phaseolus lunatus, was made according to methodology previously described [18].

Nixtamal process was conducted in the traditional way; cooking was carried out with water in ratio 1:6 adding $2 \%$ of lime $\left[\mathrm{Ca}(\mathrm{OH})_{2}\right]$, and boiling it for 80 minutes. Subsequently it was allowed to stand for 14 hours. Cooked corn obtained was washed four times with tap water and drained previous to grinding.

Table 1 shows the exact quantities of corn, protein concentrate, amino acids and water used for each treatment.

The production of dough and tortillas was made as follows: the ingredients were mixed and kneaded manually for two minutes to obtain a thin dough, without lumps and not brittle; it was allowed to stand for $2 \mathrm{~h}$. Tortillas (Photo 1) were made in a semi-automatic commercial machine. After cooking they were cool at room temperature and various physical and sensory characteristics were evaluated. Remaining tortillas were dried in an oven at $60^{\circ} \mathrm{C}$ for $24 \mathrm{~h}$ and ground to be preserved until chemical analysis.

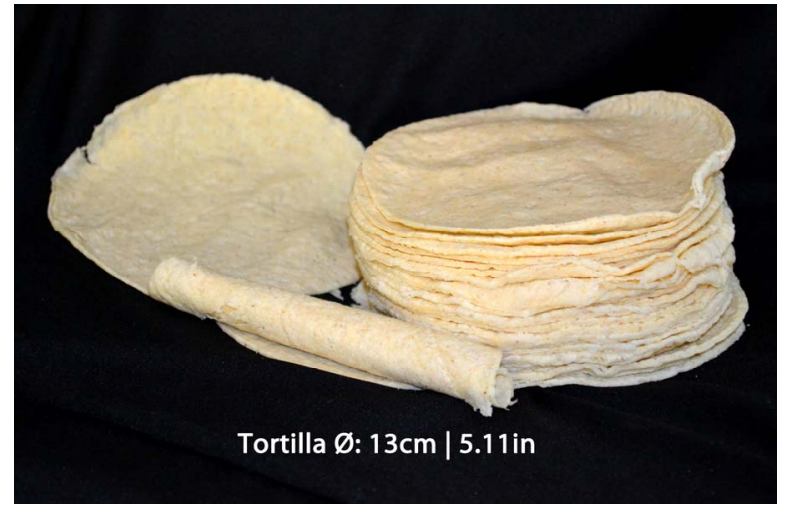

Photo 1. Tortilla shell. Individual item, stacked and rolled in a taco shape.

\subsection{Physical Characterization of Dough}

Cohesion and adhesion of the dough was measured [19]. The parameter tested was the maximum force required for tension and compression using an Instron Texturometer 4411 with a loading cell of 49 N. Samples were molded with a plastic ring of $36 \mathrm{~mm}$ diameter and $5 \mathrm{~mm}$ thick. Subsequently a load of $49 \mathrm{~N}$ at a speed of $5 \mathrm{~mm} / \mathrm{min}$ was applied form an initial distance of $6 \mathrm{~mm}$ to the plate using a compression anvil. Two programs were used on the computer, one to apply a gap of compressive force of a 4 $\mathrm{mm}$, and after a minute the second outreach program was applied to assess adhesion on the same sample.

\subsection{Physicochemical Characterization of Tortillas}

Weight loss was calculated estimating the difference between the weight of raw and baked tortilla and measured the yield of dough into final product.

Rolability is the ability to make tortillas taco-shaped without breaking. The method was carried out as follows: the tortilla was rolled around a wooden rod of $2 \mathrm{~cm}$ of diameter and the degree of rupture observed, using a subjective scale from 1 (no cracks) to 5 (cannot roll) [20].

Tensile strength and elasticity was performed on an Instron Texturometer 4411 with retention clamps. Three tortillas from each treatment were analyzed. They were cut off in strips and only the central portion of the tortilla was taken, avoiding the edges. The sample dimensions were $8 \mathrm{~cm}$ long and $2 \mathrm{~cm}$ wide and they were submitted to tension until the breaking point. The test conditions were: load cell of $49 \mathrm{~N}$, applying a maximum load of 9.8 $\mathrm{N}$, at a speed of $2 \mathrm{~mm} / \mathrm{s}$, and a displacement distance of maximum deformation of $15 \mathrm{~mm}$ [21].

Color determination was performed using a Minolta CR-200b colorimeter. Three readings were taken by placing the shutter on the sample at different points and the average reading was obtained for the following pa- 
Table 1. Treatments for the fortification of tortillas.

\begin{tabular}{|c|c|c|c|c|c|}
\hline Treatment & Dough g & Protein Concentrate $g$ & Lysine $g$ & Tryptophan g & Water $\mathrm{g}$ \\
\hline \multicolumn{6}{|l|}{ Commercial corn flour } \\
\hline Control (w/o fortification) & 400 & 0 & 0 & 0 & 555 \\
\hline Added w/Lys + Tryp & 400 & 0 & 0.826 & 0.1248 & 555 \\
\hline Added $\mathrm{w} / \mathrm{PC}+\mathrm{L}+\mathrm{T}$ & 370 & 30 & 0.596 & 0.1344 & 562 \\
\hline \multicolumn{6}{|c|}{ Grains of native maize submitted to the traditional preparation } \\
\hline Control (w/o fortification) & 500 & 0 & 0 & 0 & 132 \\
\hline Added w/Lys + Tryp & 500 & 0 & 1.446 & 0.2995 & 132 \\
\hline Added $w / P C+L+T$ & 462.5 & 37.5 & 0.884 & 0.2515 & 132 \\
\hline
\end{tabular}

rameters $\mathrm{L}^{*}, \mathrm{a}^{*}, \mathrm{~b}^{*}$ and $\Delta \mathrm{E}$.

Crude protein was determined using Kjeldahl method. The methods to quantify available $\mathrm{L}, \mathrm{T}$ and in vitro digestibility were previously described [22-24].

\subsection{Sensory Evaluation}

It was conducted with 80 untrained judges. A seven point hedonic scale was used [25]. Seven was the highest rating "I like it very much" and 1 the lowest "I dislike it very much". The analysis was performed separately in two dif- ferent sessions for each type of dough.

Data was analyzed using a one-way analysis of variance for a completely randomized design [26]. The following variables were analyzed for each one of the two factors tested (type of corn dough and type of fortification); in the dough, cohesiveness and adhesiveness; in the tortillas, crude protein, amino acid profile, available $\mathrm{L}, \mathrm{T}$, $\Delta \mathrm{E}$ protein digestibility, weight loss, rolability, elasticity and color. Treatments were compared using Duncan's multiple comparison test [26]. The statistical design applied to the sensory evaluation was a test of degree of liking, using a seven point hedonic scale, and it was analyzed by means of a one way analysis of variance [26].

\section{Results and Discussion}

\subsection{Physical Characterization of Dough}

Cohesion of tortillas made with fortified CCF dough (Table 2) was similar $(p>0.05)$. However, average results differed $(p<0.05)$ with the control group which scored the highest value. The overall results were as expected for this kind of dough, because lower values would prevent the formation of tortillas.

All results of cohesion observed in dough made with nixtamal (Table 2) were similar $(p>0.05)$. These results were in accordance to those reported previously for nixtamal fortified with vitamins, minerals and defatted soybean meal [9].

Adhesion results were similar in all treatments (Table
2) $(p>0.05)$. These values are consistent with those reported for dough produced with different types of local corn from the state of Puebla, as well as those observed recently [27-28].

\subsection{Physicochemical Characterization of Tortillas}

No changes were detected in weight loss in treatments except in fortified tortillas prepared with $\mathrm{CCF}$ which lost more weight than the control ones $(p<0.05)$ (Table 2). These results are consistent with the findings of other authors [29].

Rolability showed no changes $(p>0.05)$ attributable to the fortification. In all cases values were 1 or close to this figure. These results are similar with those reported previously with tortillas made with nixtamal or CCF $[9,30]$. Obtained rolability indicated that tortillas have sufficient flexibility to prevent breakage during taco-shaped curl.

The maximum tensile strength was observed in fortified tortillas indistinctly the dough used $(p<0.05)$. The elasticity did not change in any case. These last results are consistent with those reported by other authors who found results between 4.17 to $4.80 \mathrm{~mm}$ for tortillas made with nixtamal added with conservatives [31].

The results of color showed that the values of lightness $\left(\mathrm{L}^{*}\right), \mathrm{a}^{*}$ and $\Delta \mathrm{E}$ were similar in tortillas prepared with CCF $(p<0.05)$ (Table 3). In general, tortillas had a clear hue, with a tendency towards yellow. Similar results were obtained previously with tortillas fortified with $\mathrm{L}$ and T [32]. Only $\mathrm{b}^{*}$ values showed differences $(p<0.05)$ between the three treatments, these values were positive and relatively low, indicating a trend towards yellow.

The results of tortillas prepared with nixtamal showed that those fortified with $\mathrm{PC}+\mathrm{L}+\mathrm{T}$ showed different results $(p<0.05)$ in relation to the other two.

As expected, crude protein, available $\mathrm{L}$ and $\mathrm{T}$ content increased in all fortified tortillas with PC compared with the other two treatments $(p<0.05)$ (Table 4). T content for fortified tortillas exceeded the requirements estab- 
Table 2. Physiochemical properties of the dough of maize.

\begin{tabular}{|c|c|c|c|c|c|}
\hline Treatment & Cohesion $\mathrm{N}$ & Adhesion N & Weight lost \% & Tensile strength $\mathrm{N}$ & Elasticity $\mathrm{mm}$ \\
\hline \multicolumn{6}{|l|}{ Commercial corn flour } \\
\hline Control (w/o fortification) & $34.49^{\mathrm{a}}$ & $25.09^{\mathrm{a}}$ & $26.4^{\mathrm{a}}$ & $0.6429^{\mathrm{a}}$ & $4.427^{\mathrm{a}}$ \\
\hline Added w/Lys + Tryp & $29.20^{\mathrm{b}}$ & $24.40^{\mathrm{a}}$ & $32.4^{\mathrm{b}}$ & $0.9202^{\mathrm{b}}$ & $4.565^{\mathrm{a}}$ \\
\hline Added w $/ \mathrm{PC}+\mathrm{L}+\mathrm{T}$ & $27.64^{\mathrm{b}}$ & $19.99^{\mathrm{a}}$ & $29.9^{\mathrm{b}}$ & $0.8389^{b}$ & $4.130^{\mathrm{a}}$ \\
\hline \multicolumn{6}{|c|}{ Grains of native maize submitted to the traditional preparation } \\
\hline Control (w/o fortification) & $48.80^{\mathrm{a}}$ & $25.09^{\mathrm{a}}$ & $26.3^{\mathrm{a}}$ & $0.5236^{\mathrm{a}}$ & $4.429^{\mathrm{a}}$ \\
\hline Added w/Lys + Tryp & $49.19^{\mathrm{a}}$ & $23.72^{\mathrm{a}}$ & $27.0^{\mathrm{a}}$ & $0.9643^{\mathrm{b}}$ & $5.237^{\mathrm{a}}$ \\
\hline Added $\mathrm{w} / \mathrm{PC}+\mathrm{L}+\mathrm{T}$ & $49.19^{\mathrm{a}}$ & $24.50^{\mathrm{a}}$ & $28.6^{\mathrm{a}}$ & $0.9202^{\mathrm{b}}$ & $5.149^{\mathrm{a}}$ \\
\hline
\end{tabular}

${ }^{\mathrm{a}, \mathrm{b}, \mathrm{c}}$ Different letters in the same column, for each type of flour, means $(p<0.05)$.

Table 3. Color properties of tortillas.

\begin{tabular}{|c|c|c|c|c|}
\hline Treatment & $\mathrm{L}^{*}$ & $a^{*}$ & $\mathrm{~b}^{*}$ & $\Delta \mathrm{E}$ \\
\hline \multicolumn{5}{|l|}{ Commercial corn flour } \\
\hline Control (w/o fortification) & $74.0^{\mathrm{a}}$ & $-1.5^{\mathrm{a}}$ & $14.7^{\mathrm{a}}$ & $26.4^{\mathrm{a}}$ \\
\hline Added w/Lys + Tryp & $74.7^{\mathrm{a}}$ & $-1.4^{\mathrm{a}}$ & $15.8^{\mathrm{b}}$ & $26.3^{\mathrm{a}}$ \\
\hline Added $\mathrm{w} / \mathrm{PC}+\mathrm{L}+\mathrm{T}$ & $74.4^{\mathrm{a}}$ & $-1.1^{\mathrm{a}}$ & $17.3^{\mathrm{c}}$ & $27.3^{\mathrm{a}}$ \\
\hline \multicolumn{5}{|c|}{ Grains of native maize submitted to the traditional preparation } \\
\hline Control (w/o fortification) & $72.6^{\mathrm{a}}$ & $-0.9^{\mathrm{a}}$ & $35.6^{\mathrm{a}}$ & $41.4^{\mathrm{a}}$ \\
\hline Added w/Lys + Tryp & $70.6^{\mathrm{ab}}$ & $-0.3^{\mathrm{a}}$ & $35.9^{\mathrm{a}}$ & $42.9^{\mathrm{a}}$ \\
\hline Added $\mathrm{w} / \mathrm{PC}+\mathrm{L}+\mathrm{T}$ & $68.3^{\mathrm{b}}$ & $-1.4^{\mathrm{b}}$ & $26.2^{\mathrm{b}}$ & $37.5^{\mathrm{b}}$ \\
\hline
\end{tabular}

${ }^{a, b, c}$ Different letters in the same column, for each type of flour, means $(p<0.05)$.

Table 4. Nutritional content of tortillas.

\begin{tabular}{|c|c|c|c|c|}
\hline Treatment & Crudeprotein & Available lysine & Tryptophan & In vitro digestibility \\
\hline \multicolumn{5}{|l|}{ Commercial corn flour } \\
\hline Control (w/o fortification) & $8.9^{\mathrm{a}}$ & $2.97^{\mathrm{a}}$ & $1.04^{\mathrm{a}}$ & $84.9^{\mathrm{a}}$ \\
\hline Added w/Lys + Tryp & $9.0^{\mathrm{a}}$ & $4.99^{\mathrm{b}}$ & $1.80^{\mathrm{b}}$ & $88.5^{\mathrm{b}}$ \\
\hline Added $\mathrm{w} / \mathrm{PC}+\mathrm{L}+\mathrm{T}$ & $13.7^{\mathrm{b}}$ & $5.56^{\mathrm{b}}$ & $1.74^{\mathrm{b}}$ & $90.2^{\mathrm{c}}$ \\
\hline \multicolumn{5}{|c|}{ Grains of native maize submitted to the traditional preparation } \\
\hline Control (w/o fortification) & $11.7^{\mathrm{a}}$ & $3.18^{\mathrm{a}}$ & $1.99^{\mathrm{a}}$ & $81.5^{\mathrm{a}}$ \\
\hline Added w/Lys + Tryp & $11.8^{\mathrm{a}}$ & $5.34^{\mathrm{b}}$ & $2.57^{\mathrm{b}}$ & $86.7^{\mathrm{b}}$ \\
\hline Added $\mathrm{w} / \mathrm{PC}+\mathrm{L}+\mathrm{T}$ & $16.5^{\mathrm{b}}$ & $5.75^{\mathrm{b}}$ & $2.53^{\mathrm{b}}$ & $88.6^{\mathrm{c}}$ \\
\hline
\end{tabular}

${ }^{\mathrm{a}, \mathrm{b}, \mathrm{c}}$ Different lettersinthe same column, for each type of flour, indicates $(p<0.05)$.

lished by the FAO of $1.1 \mathrm{~g} / 100 \mathrm{~g}$ protein [6].

Despite the significant increase in the content of $\mathrm{L}$, this did not meet the requirements established by FAO [6]. Probably the heat treatment undergoing tortillas processing affected $\mathrm{L}$ availability. With heat, a reaction occurs between the amino group of lysine and the amino group of asparagine and glutamine, leading to a crosslinking, reducing enzymatic attack in the digestive track. Also crosslinking reactions occur between polypeptide chains by acylation of free amino groups. All these induce a decrease in L availability [33].
Fortification favorably affected the digestibility of all tortillas. The best results were obtained with the treatment of $\mathrm{PC}+\mathrm{L}+\mathrm{T}(p<0.05)$. These results were similar to those obtained for tortillas supplemented with $8 \%$ of soybean meal [3].

\subsection{Sensory Evaluation}

The overall results were similar $(p>0.05)$ for control tortillas and those fortified with $\mathrm{L}+\mathrm{T}$. The addition of PC led to a decrease $(p<0.05)$ in almost all parameters compared with the control group, but did not mean a re- 
Table 5. Sensory evaluation of tortillas.

\begin{tabular}{|c|c|c|c|}
\hline Treatment & Color & Odor & Taste \\
\hline \multicolumn{4}{|l|}{ Commercial corn flour } \\
\hline Control (w/o fortification) & $5.13^{\mathrm{a}}$ & $5.25^{\mathrm{a}}$ & $4.95^{\mathrm{a}}$ \\
\hline Added w/Lys + Tryp & $5.47^{\mathrm{a}}$ & $5.53^{\mathrm{a}}$ & $5.40^{\mathrm{b}}$ \\
\hline Added $\mathrm{w} / \mathrm{PC}+\mathrm{L}+\mathrm{T}$ & $5.41^{\mathrm{a}}$ & $4.83^{b}$ & $4.17^{\mathrm{c}}$ \\
\hline \multicolumn{4}{|c|}{ Grains of native maize submitted to the traditional preparation } \\
\hline Control (w/o fortification) & $5.56^{\mathrm{a}}$ & $5.51^{\mathrm{a}}$ & $5.44^{\mathrm{a}}$ \\
\hline Added w/Lys + Tryp & $5.58^{\mathrm{a}}$ & $5.34^{\mathrm{a}}$ & $5.08^{\mathrm{a}}$ \\
\hline Added $\mathrm{w} / \mathrm{PC}+\mathrm{L}+\mathrm{T}$ & $2.91^{\mathrm{b}}$ & $4.89^{b}$ & $4.30^{\mathrm{b}}$ \\
\hline
\end{tabular}

jection, as mean values of 4 represent "I do not like, nor dislike it" (Table 5).

\section{Conclusion}

The fortification of a commercial corn flour or nixtamal, with either, a protein concentrate from Phaseolus lunatus alone or in combination with lysine and tryptophan, did not altered rolability or elasticity in the tortillas elaborated thereafter. Few changes were attributed to fortification on tensile strength or color. Fortification improved amino acid content and in vitro digestibility, without negative effects on acceptance of obtained tortillas.

\section{REFERENCES}

[1] INEGI (National Institute of Statistics, Geography and Informatics), "Population and Housing Census," México DF, 2010 .

[2] M. Sierra-Macías, A. Palafox-Caballero, G. Vázquez-Carrillo, F. Rodríguez-Montalvo and A. Espinosa-Calderón, "Agronomic Characterization, Industrial and Nutritional Quality of Corn Cultivated in Tropical areas of México," Agronomy in Mesoamérica,Vol. 21, 2010, pp. 21-29.

[3] S. S. Serna, "Nutritive Value of Tortillas Fortified with Soybeans," Soyanoticias, Vol. 251, 1997, pp. 1-6.

[4] E. Cruz-Huerta and I. Verdalet-Guzmán, "Corn Tortillas: A Nutritivetradition," The Magazine of Science and Mankind, Vol. 20, No. 3, 2007, pp. 41-44.

[5] J. Landry and T. Moureaux, "Distribution and Amino Acid Composition of Protein Fractions in Opaque-2 Maize-grain," Phytochemistry, Vol. 21, No. 8, 1982, pp. 18651869. doi:10.1016/0031-9422(82)83004-5

[6] FAO/WHO, "Protein Quality Evaluation. Report of Joint FAO/WHO Expert Consultation. Food and Nutrition," Paper No. 51, Food Agriculture Organizations and the World Health Organization, Rome, Italy, 1991.

[7] FAO, "The State of Food Insecurity in the World," 2009. http://www.fao.org/docrep/003/y1500e/y1500e00.htm

[8] Encuesta Nacional de Salud y Nutrición, "Mexican Na- tional Health and Nutrition Survey," Instituto Nacional de Salud Pública, Cuernavaca, 2006.

[9] J. D. Figueroa-Cárdenas, M. G. Acero-Godínez, N. L. Vasco-Méndez, A. Lozano-Guzmán, L. M. Flores-Acosta and J. González-Hernández, "Fortification and Evaluation of the Nixtamal Tortillas," American Archives of Nutrition, Vol. 51, No. 3, 2001, pp. 293-302.

[10] G. Massieu, O. Y. Cravioto, R. O. Cravioto and F. de M. Figueroa, "Evaluation of Protein and Amino Acids in Mexican Diets. 111. Protein Efficiency of Tortilla-Based Diets Supplemented with Beans, Peas or Milk Using the Growing White Rat Methodology," Science (Mexican Journal), Vol. 14, 1954, pp. 93-97.

[11] R. O. Cravioto and M. M. Cervantes, "Protein Efficiency Corn Dough Enriched with Soybean Flour or with Sesame Protein," Science (Mexican Journal), Vol. 24, 1965, pp. 159-162.

[12] M. A. Sánchez and S. Maya, "Industrial Corn Flour Enrichment with Whole Amaranth Flour and Milling Fractions in Corn-Based Products," American Archives of Nutrition, Vol. 35, No. 3, 1985, pp. 518-537.

[13] H. Uc-Cetz, V. Pérez-Flores, L. Chel-Guerrero and A. Betancur-Ancona, "Production of Corn Tortillas Added with a Protein Concentrate Form Phaseolus lunatus," Food Technology, Vol. 38, No. 1, 2003, pp. 7-16.

[14] V. A. Obatolu, A. Okoruwa and J. E. Iken, "Improvement of Home-Made Maize Tortilla with Soybean," International Journal of Food Science and Technology, Vol. 42, No. 4, 2007, pp. 420-426. doi:10.1111/j.1365-2621.2006.01242.x

[15] M. L. Hurtado, B. A. Escobar and A. M. Estévez, "Deep Frying Snack Product of Legume/Cereal Mixture Based on Corn and Three Varieties of Beans," American Archives of Nutrition, Vol. 51, No. 3, 2001, pp. 303-308.

[16] A. M. Estévez, B. Escobar, I. Zacarras and M. L. Hurtado, "Nutritional Evaluation and Accelerated Storage at $37^{\circ} \mathrm{C}$ of Fried Bean and Corn Mixtures," American Archives of Nutrition, Vol. 53, No.1, 2003, pp. 70-73.

[17] J. E. Briones, M. I.Cuatzo, F. López and Y. T. Gallardo, "Development of Tamales (Corn Patties) from Precooked Corn-Soybean Flour by Extrusion," Proceedings of the XII Food Science and Technology Congress, Guanajuato, 27-28 May 2010.

[18] L. Chel-Guerrero, V. Pérez-Flores, D. Betancur-Ancona and G. Dávila-Ortiz, "Functional Properties of Flours and Protein Isolates from Phaseolus lunatus and Canavalia ensiformis Seeds," Journal of Agricultural and Food Chemistry, Vol. 50, No. 3, 2002, pp. 584-591. doi:10.1021/jf010778j

[19] B. Ramirez-Wong, V. E. Sweat, P. I. Torres and L. W. Rooney, "Development of Two Instrumental Methods for Corn Masa Texture Evaluation," Cereal Chemistry, Vol. 70, No. 3, 1993, pp. 286-290.

[20] S. Bedolla, "Development and Characterization of Instant Tortilla Flours from Sorghum and Corn by Infra-Red Cooking (Micronixing) and Extrusion Cooking," Ph.D. Dissertation, A \& M University, College Station, 1983. 
[21] V. G. Arámbula, A. L. Barrón, H. J. González and M. E. Moreno, "Effects of Cook and Steep Time of Nixtamalized Corn Grain (Zea mayz L.) on the Physicochemical, Rheological, Structural and Textural Characteristics of Grain, Masa and Tortillas," American Archives of Nutrition, Vol. 51, No. 2, 2001, pp. 187-194.

[22] V. H. Booth, "Problems in the Determination of FDNBAvailable Lysine," Journal of Food Science and Agriculture, Vol. 22, No. 12, 1972, pp. 658-665. doi:10.1002/jsfa.2740221214

[23] R. J. Spies and D. C. Chambers, "Chemical Determination of Tryptophan in Proteins," Analytical Chemestry, Vol. 21, No. 10, 1949, pp. 1249-1246. doi:10.1021/ac60034a033

[24] H. Hsu, O. Vavak, L. Satterlee and G. A. Miller, "Multienzime Technique for Estimating Protein Digestibility," Journal of Food Science, Vol. 42, 1977, pp. 1269-1279. doi:10.1111/j.1365-2621.1977.tb14476.x

[25] M. R. Torricela, U. E. Zamora and A. H. Pulido, "Sensory Evaluation Applied to the Development of Quality in the Food Industry," Research Institute for the Food Industry, La Habana, 1989.

[26] D. Montgomery, "Designs and Analysis of Experiments," Limusa-Wiley, México DF, 2004.

[27] E. Rangel-Meza, A. Muñoz-Orozco, G. Vázquez-Carrillo, J. Cuevas-Sánchez, J. Merino-Castillo and S. MirandaColin, "Alkaline Cooking, Preparation and Quality of Corn Tortillas form Ecatlán, Puebla, México," Agroscience, Vol. 38, No. 1, 2004, pp. 53-61.

[28] F. J. Solorza, L. Chel, P. J. Parra, D. Betancura and A. F.
Castellanos, "Rheological and Mechanical Evaluation of Maize Dough and Tortillas Containing Cassava and Malanga Flour," International Journal of Food Science and Technology, 2012, in Press.

[29] R. A. Mauricio-Sánchez, J. Figueroa-Cárdenas, S. Taba, M. Reyes-Vega, F. Rincón-Sánchez and A. Mendoza-Galván, "Characterization of Maize Accessions by Grain and Tortilla Quality Traits," Crop Production Magazine, Vol. 27, No. 3, 2004, pp. 213-222.

[30] R. Flores-Farías, F. Martínez-Bustos, Y. Salinas-Moreno, Y. Kil-Chang, J. González-Hernández and E. Ríos, "Physicochemical and Rheological Characteristics of Commercial Nixtamalized Mexican Maize Flours for Tortillas," Journal of the Science of Food and Agriculture, Vol. 80,2000 , pp. 657-664.

doi:10.1002/(SICI)1097-0010(20000501)80:6<657::AIDJSFA576>3.0.CO;2-J

[31] O. J. J. Ordaz and C. G. M. Vázquez, "Shelf Life and Sensory Evaluation in Corn Tortillas Made with Preservative Enhancers," American Archives of Nutrition, Vol. 4, 1997, pp. 372-376.

[32] K. N. Waliszewski, Y. Estrada and V. Pardío, "Sensory Properties Changes of Fortified Nixtamalized Corn Flour with Lysine and Tryptophan during Storage," Plant Foods for Human Nutrition, Vol. 59, No. 1-4, 2004, pp. 23-31.

[33] V. Quitral, L. Abugoch, J. Vinagre and M. Larraín, "Effect of Thermal Treatments on the Chemical Characteristics of Mora Crab Meat (Homalaspisplana)," American Archives of Nutrition, Vol. 53, No. 1, 2003, pp. 90-95. 